\title{
Hubungan Faktor Sosial Ekonomi dan Ketahanan Pangan terhadap Kejadian Stunting pada Balita
}

\section{Relationship of Social Economic and Food Security Factors on Stunting Incidence in Children under Five Years}

\author{
Dyah Wulan Sumekar Rengganis Wardani ${ }^{1}$, Marita Wulandari ${ }^{2}$, Suharmanto $^{3}$ \\ ${ }^{1,3}$ Fakultas Kedokteran, Universitas Lampung, Indonesia \\ ${ }^{2}$ Dinas Kesehatan Kota Bandar Lampung, Provinsi Lampung, Indonesia
}

\section{ARTICLE INFO}

\section{Article history}

Received date

02 Sept 2020

Revised date

09 Sept 2020

Accepted date

17 Sept 2020

Keywords:

Food security;

Social economic;

Stunting;

Toddler.

\section{Kata kunci:}

Ketahanan pangan;

Sosial ekonomi;

Stunting;

Balita.

\author{
ABSTRACT/ ABSTRAK
}

\begin{abstract}
Indonesia ranks third as a country with the highest stunting prevalence in Southeast Asia in 2017. Bandar Lampung, is one of the cities with a high prevalence of stunting; and Teluk Betung Selatan Subdistrict is an area with the highest prevalence of stunting in Bandar Lampung. This study aims to analyze the relationship between socioeconomic factors and food security on the incidence of stunting in children under five years. This study is a case-control study, with a case sample of 50 families who have stunted children under five years and the control sample is $\mathbf{5 0}$ families who have normal children under five years. The research variables included socioeconomic factors (education and income), food security factors (family food insecurity and food diversity), and the incidence of stunting, which were then analyzed by Chi-Square. The results showed that there was a relationship between socioeconomic factors and family food insecurity to the incidence of stunting. Therefore, stunting control programs need to involve these two factors in the intervention to reduce stunting in children under five years.
\end{abstract}

\begin{abstract}
Indonesia menempati urutan ketiga negara dengan prevalensi stunting tertinggi di Asia Tenggara pada tahun 2017. Bandar Lampung, merupakan salah satu kota dengan prevalensi stunting tinggi; dan Kecamatan Teluk Betung Selatan merupakan wilayah dengan prevalensi stunting tertinggi di Bandar Lampung. Penelitian ini bertujuan menganalisis hubungan faktor sosial ekonomi dan ketahanan pangan terhadap kejadian stunting pada balita. Penelitian ini merupakan penelitian case control, dengan sampel kasus adalah 50 keluarga yang mempunyai balita stunting dan sampel kontrol adalah 50 keluarga yang mempunyai balita normal. Variabel penelitian mencakup faktor sosialekonomi (pendidikan dan pendapatan), faktor ketahanan pangan (kerawanan pangan keluarga dan keragaman makanan) serta kejadian stunting, yang kemudian dianalisis dengan Chi Square. Hasil penelitian menunjukkan terdapat hubungan antara faktor sosialekonomi dan kerawanan pangan keluarga terhadap kejadian stunting. Oleh karena itu, program pengendalian stunting perlu melibatkan kedua faktor tersebut dalam intervensi penurunan stunting pada balita.
\end{abstract}

Corresponding Author:

Dyah Wulan Sumekar Rengganis Wardani

Fakultas Kedokteran, Universitas Lampung, Indonesia

Email: dyah.wulan@fk.unila.ac.id

\section{PENDAHULUAN}

Stunting merupakan suatu kondisi anak dengan panjang atau tinggi badan kurang dari normal, yang biasanya disertai dengan komplikasi penyakit (Khoeroh \& Indriyanti,
2015). Stunting masih menjadi masalah gizi anak bawah lima tahun (balita) di Indonesia. Pada tahun 2017, diperkirakan terdapat sekitar 150,8 juta balita menderita stunting; setara dengan $22,2 \%$ dari keseluruhan balita. Di Indonesia, ratarata prevalensi balita stunting pada tahun 2005- 
2017 sebesar 36,4\% dan Indonesia menempati urutan ketiga sebagai negara dengan prevalensi stunting tertinggi di kawasan Asia Tenggara. Lebih lanjut, merujuk pada standar World Health Organization (WHO), prevalensi stunting di suatu daerah dikategorikan baik bila kurang dari 20\% (Kementerian Kesehatan RI, 2018).

Dampak stunting tidak hanya pada individu tetapi juga terhadap bangsa dan negara. Dampak stunting pada individu mencakup peningkatan morbiditas dan mortalitas, peningkatan biaya kesehatan, penurunan kognitif, penurunan prestasi dan kapasitas belajar hingga penurunan kemampuan serta kapasitas kerja, yang akhirnya berdampak pada pembangunan bangsa (World Health Organization, 2013; Oktarina \& Sudiarti, 2014). Lebih lanjut, dampak stunting juga dapat bersifat jangka pendek maupun jangka panjang. Dampak jangka pendek anak dapat berupa kerentanan anak terhadap infeksi dan perkembangan kognitif yang kurang maksimal. Sedangkan dampak jangka panjang lebih kepada meningkatnya risiko pada saat dewasa terhadap penyakit kronis seperti diabetes atau penyakit kardiovaskuler (Prendergast \& Humphrey, 2014; Nurbaiti, dkk., 2014). Merujuk pada dampak stunting tersebut, pencegahan dan pengendalian kejadian stunting sangat diperlukan, dan untuk itu diperlukan informasi mengenai faktor-faktor yang perlu diintervensi.

Terdapat beberapa faktor yang secara langsung maupun tidak langsung mempengaruhi kasus stunting, diantaranya faktor sosial ekonomi dan ketahanan pangan (Tiwari, et al., 2014; UNICEF, 2013; Michaelsen, et al., 2015). Faktor sosial ekonomi merujuk pada pendidikan, pekerjaan, pendapatan, kelas sosial, ras/ etnis dan gender yang menyebabkan seseorang mempunyai perbedaan dalam mengakses pelayanan kesehatan, yang salah satu dampaknya adalah meningkatkan risiko terjadinya stunting dan wasting (CSDH, 2011; UNICEF, 2013). Sedangkan ketahanan pangan merujuk pada tersedianya pangan yang cukup, baik jumlah maupun mutunya, aman, beragam, bergizi, merata, dan terjangkau serta tidak bertentangan dengan agama, keyakinan, dan budaya masyarakat, untuk dapat hidup sehat, aktif, dan produktif secara berkelanjutan (Pemerintah RI, 2012). Pada masalah gizi, ketahanan pangan dapat diidentifikasi dari kemampuan rumah tangga untuk mengakses pangan dan keragaman konsumsi pangan rumah tangga (Coates, 2007).

Pemantauan status gizi tahun 2018 di Bandar Lampung mempunyai prevalensi balita stunting $33,4 \%$, lebih besar dari ketentuan WHO yang hanya $20 \%$. Lebih lanjut, Kecamatan Teluk
Betung Selatan merupakan kecamatan dengan prevalensi stunting tertinggi di Bandar Lampung dan mengalami peningkatan jumlah balita stunting. Merujuk pada data tahun 2015 terdapat 90 balita stunting dan pada tahun 2018 meningkat menjadi 310 balita (Dinas Kesehatan Kota Bandar Lampung, 2015; Dinas Kesehatan Kota Bandar Lampung, 2018). Di sisi lain, belum banyak penelitian yang mempelajari hubungan antara faktor sosial ekonomi dan ketahanan pangan terhadap kejadian stunting di wilayah tersebut. Merujuk pada uraian di atas, maka penelitian ini bertujuan menganalisis hubungan faktor sosial ekonomi dan ketahanan pangan terhadap kejadian stunting pada balita.

\section{METODE}

Penelitian ini merupakan penelitian case control yang dilakukan di Kecamatan Teluk Betung, Kota Bandar Lampung pada bulan AprilMei 2019. Populasi penelitian adalah seluruh balita berusia 12-59 bulan yang telah dilakukan pengukuran tinggi badan pada bulan NovemberDesember 2018 yang berjumlah 1.633 balita, yang terdiri dari populasi kasus sebanyak 310 balita dan populasi kontrol sebanyak 1.323 balita. Sampel kelompok kasus dan kelompok kontrol masing-masing adalah 50 balita, sesuai dengan penghitungan jumlah sampel dengan menggunakan proporsional random sampling.

Variabel pada penelitian ini terdiri dari variabel dependen dan variabel independen. Variabel dependen adalah kejadian stunting yaitu tinggi balita dibandingkan dengan height-for-age Z skor yang dalam penelitian ini dikategorikan menjadi stunting; tidak stunting (World Health Organization, 2006). Variabel independen terdiri dari pendidikan ibu, pendapatan keluarga, ragam makanan dan kerawanan pangan keluarga. Pendidikan ibu adalah lama pendidikan 12 tahun yang ditamatkan, yang pada penelitian ini dikateogirkan menjadi tidak tamat dan tamat (Pemerintah RI, 2008). Pendapatan keluarga adalah jumlah seluruh pendapatan keluarga per bulan yang dikategorikan menjadi rendah: $<$ Rp1.500.000, sedang: Rp1.500.000-<Rp3.750.000, dan tinggi: $\geq$ Rp3.750.000 (Badan Pusat Statistik Provinsi Lampung, 2016). Ragam makanan didefinisikan sebagai jumlah keragaman pemberian pangan rumah tangga setiap hari, yang pada penelitian ini dikategorikan menjadi rendah: $\leq 3$ jenis, sedang: $4-5$ jenis, dan tinggi: $\geq 6$ jenis) (Food and Agricultural Organization, 2011). Variabel kerawanan pangan keluarga pada penelitian ini diukur dengan Household Food 
Insecurity Access Scale (HFIAS), yang kemudian dikategorikan menjadi rawan berat, rawan sedang, rawan ringan, dan tahan pangan) (Coates, 2007);

Pengumpulan data dilakukan dengan cara pengambilan data primer dan data sekunder. Data sekunder mencakup data balita stunting dan balita bukan stunting. Sedangkan data primer mencakup data ketahanan pangan dan sosial ekonomi. Pengumpulan data dilakukan dengan wawancara terhadap responden (ibu/ pengasuh anak) dengan alat bantu kuesioner. Pengolahan data pada penelitian ini mencakup editing, coding dan entry data. Analisis data yang digunakan terdiri dari analisis univariat untuk mengetahui gambaran tiap indikator serta analisis bivariat untuk mengetahui hubungan dan kekuatan hubungan antara variabel independen dan variabel dependen. Penelitian ini telah mendapatkan persetujuan etik dari Fakultas Kedokteran Universitas Lampung dengan Nomor 784/UN26.18/PP.05.02.00/2019. Selain itu, keikutsertaan responden dalam penelitian ini adalah berdasarkan sukarela tanpa paksaan.

\section{HASIL}

Tabel 1. Analisis Data Univariat

\begin{tabular}{lll}
\hline \multicolumn{1}{c}{ Variabel } & n & \% \\
\hline Pendidikan ibu & & \\
$\quad$ Tidak tamat pendidikan dasar & 46 & 46 \\
$\quad$ Tamat pendidikan dasar & 54 & 54 \\
$\begin{array}{l}\text { Pendapatan keluarga } \\
\text { Rendah }\end{array}$ & 29 & 29 \\
$\quad$ Sedang & 52 & 52 \\
$\quad$ Tinggi & 19 & 19 \\
Keragaman pangan keluarga & & \\
$\quad$ Rendah - sedang & 10 & 10 \\
$\quad$ Tinggi & 90 & 90 \\
Kerawanan pangan keluarga & & \\
$\quad$ Rawan berat & 12 & 12 \\
$\quad$ Rawan sedang & 18 & 18 \\
$\quad$ Rawan ringan & 23 & 23 \\
$\quad$ Tahan pangan & 47 & 47 \\
\hline
\end{tabular}

Pada tabel 1 dapat diketahui bahwa responden pada penelitian ini lebih banyak (54\%) merupakan responden dengan pendidikan ibu tamat pendidikan dasar, walaupun perbedaan persentase dengan pendidikan ibu tidak tamat pendidikan dasar tidak terlalu besar. Lebih lanjut, responden pada penelitian ini lebih banyak mempunyai pendapatan keluarga yang sedang (52\%). Untuk ketahanan pangan, responden dalam penelitian ini lebih banyak (90\%) mempunyai keragaman pangan yang tinggi serta dalam kategori tahan pangan (47\%), walaupun tidak terlalu banyak perbedaan persentase dengan kategor kerawanan pangan keluarga lainnya.

Tabel 2. Analisis Data Faktor Sosial Ekonomi dan Ketahanan Pangan terhadap Kejadian Stunting

\begin{tabular}{|c|c|c|c|c|c|c|}
\hline \multirow{2}{*}{ Variabel } & \multicolumn{2}{|c|}{ Stunting } & \multicolumn{2}{|c|}{ Tidak stunting } & \multirow{2}{*}{ p-value } & \multirow{2}{*}{ Nilai C } \\
\hline & $\mathbf{n}$ & $\%$ & $\mathbf{n}$ & $\%$ & & \\
\hline \multicolumn{7}{|l|}{ Pendidikan ibu } \\
\hline Tidak tamat pendidikan dasar & 32 & 69,6 & 14 & 30,4 & \multirow{2}{*}{0,001} & \multirow{2}{*}{0,340} \\
\hline Tamat pendidikan dasar & 18 & 33,3 & 36 & 66,7 & & \\
\hline \multicolumn{7}{|l|}{ Pendapatan keluarga } \\
\hline Rendah & 24 & 82,8 & 5 & 17,2 & \multirow{3}{*}{$<0,001$} & \multirow{3}{*}{0,444} \\
\hline Sedang & 24 & 46,2 & 28 & 53,8 & & \\
\hline Tinggi & 2 & 10,5 & 17 & 89,5 & & \\
\hline \multicolumn{7}{|l|}{ Keragaman pangan keluarga } \\
\hline Rendah - sedang & 8 & 80 & 2 & 20 & \multirow{2}{*}{0,096} & \multirow{2}{*}{0,146} \\
\hline Tinggi & 42 & 46,7 & 48 & 53,3 & & \\
\hline \multicolumn{7}{|l|}{ Kerawanan pangan keluarga } \\
\hline Rawan berat & 9 & 75,0 & 3 & 25 & \multirow{4}{*}{$<0,001$} & \multirow{4}{*}{0,415} \\
\hline Rawan sedang & 15 & 83,3 & 3 & 16,7 & & \\
\hline Rawan ringan & 13 & 56,5 & 10 & 43,5 & & \\
\hline Tahan pangan & 13 & 27,7 & 34 & 72,3 & & \\
\hline
\end{tabular}



Pada tabel 2 dapat diketahui bahwa pada balita stunting lebih banyak $(69,6 \%)$ merupakan ibu yang tidak tamat pendidikan dasar dan memiliki pendapatan keluarga yang rendah $(82,8 \%)$. Sedangkan pada balita yang tidak stunting lebih banyak (66,7\%) merupakan ibu yang menamatkan pendidikan dasar dan dengan pendapatan keluarga yang tinggi $(89,5 \%)$. Hasil analisis bivariat antara pendidikan ibu dan stunting diperoleh nilai $p$-value $=0,001$ dan nilai $\mathrm{C}=0,340$ yang berarti terdapat hubungan antara pendidikan dan kejadian stunting pada balita. Demikian pula pada analisis bivariat antara pendapatan keluarga dengan stunting diperoleh nilai $p$-value $=<0,001$ yang berarti terdapat hubungan antara pendapatan keluarga dengan kejadian stunting pada balita.

Untuk faktor ketahanan pangan, merujuk tabel 2, pada balita stunting lebih banyak merupakan keluarga dengan kerawanan pangan keluarga kategori rawan berat $(75,0 \%)$ dan rawan sedang $(83,3 \%)$ serta keragaman pangan keluarga yang rendah - sedang (80\%). Sedangkan pada balita yang tidak stunting lebih banyak $(72,3 \%)$ merupakan keluarga yang tahan pangan dan dengan keragaman pangan keluarga yang tinggi $(53,3 \%)$. Hasil analisis hubungan antara keragaman pangan keluarga dan stunting dengan Chi Square mendapatkan nilai $p$-value $=0,096$ yang menunjukkan tidak terdapat hubungan antara keragaman pangan keluarga dan kejadian stunting pada balita. Sedangkan hasil analisis hubungan antara kerawanan pangan keluarga dan stunting mendapatkan nilai $p$-value $<0,001$ dan nilai $\mathrm{C}=0,415$ yang berarti terdapat hubungan erat antara kerawanan pangan keluarga dan kejadian stunting pada balita.

\section{PEMBAHASAN}

Hasil penelitian ini mendapatkan bahwa sebagian besar responden mempunyai sosial ekonomi yang cukup baik yang ditunjukkan dengan pendidikan yang tinggi dan pendapatan yang sedang. Akan tetapi, merujuk pada tabel 2, responden dengan pendidikan tinggi dan pendapatan sedang tidak merata di semua kelompok responden. Responden dengan balita stunting lebih banyak merupakan responden dengan pendidikan rendah dan pendapatan rendah, sedangkan responden dengan balita tidak stunting lebih banyak merupakan responden dengan pendidikan tinggi dan pendapatan tinggi. Hasil tersebut didukung dengan hasil analisis data yang menunjukkan terdapatnya hubungan antara faktor sosial ekonomi (pendidikan dan pendapatan) terhadap kejadian stunting pada anak balita. Faktor sosial ekonomi yang rendah, diantaranya adalah pendidikan dan pendapatan yang rendah, akan menyebabkan terjadinya stratifikasi sosial ekonomi dalam masyarakat yang pada akhirnya akan mengakibatkan perbedaan akses terhadap sarana prasarana kesehatan. Perbedaan akses tersebut akan menyebabkan terjadinya perbedaan peluang kejadian penyakit dan kematian, termasuk kejadian stunting pada balita (CSDH, 2011). Faktor sosial ekonomi juga sangat berkaitan dengan akses terhadap sanitasi lingkungan dan sumber air bersih yang sangat terkait dengan penyakit-penyakit infeksi pada balita, yang dapat meningkatkan risiko kejadian stunting pada balita (Budge, et al., 2019). Walaupun tidak mempelajari mengenai stunting, hasil penelitian ini juga sesuai dengan penelitian di Bandar Lampung yang mendapatkan hasil bahwa faktor sosial ekonomi berpengaruh terhadap kesehatan, khususnya kejadian tuberkulosis (TB) (Wardani \& Wahono, 2018).

Lebih lanjut, seseorang dengan pendidikan tinggi akan mempunyai kemungkinan yang lebih besar untuk mendapatkan pekerjaan dan pendapatan yang baik; sehingga akan memungkinkan untuk mendapatkan kesejahteraan termasuk kesehatan yang baik (Braveman, Egerter, \& Mockenhaupt, 2011). Pada penelitian ini, keluarga dengan pendapatan keluarga yang sedang-tinggi lebih banyak merupakan keluarga dengan pendidikan ibu yang tinggi, sedangkan keluarga dengan pendapatan keluarga yang rendah lebih banyak merupakan keluarga dengan pendidikan ibu yang juga rendah.

Merujuk pada nilai coeficient contingency, pada penelitian ini pendapatan $(\mathrm{C}=0,444)$ merupakan faktor yang lebih kuat korelasinya dibandingkan pendidikan $(\mathrm{C}=0,340)$. Hasil penelitian ini sesuai dengan penelitian di Peru yang mendapatkan hasil bahwa produk domestik bruto per kapita menunjukkan korelasi yang signifikan dalam analisis yang disesuaikan dengan waktu terhadap penurunan kasus stunting tahunan (Huicho, et.al., 2017). Penelitian ini juga sesuai dengan penelitian yang dilakukan di Semarang 
yang mendapatkan hasil bahwa penentu utama kasus stunting bayi usia 6 bulan adalah tingkat pendapatan keluarga (Mustikaningrum, dkk., 2016).

Hasil penelitian juga menunjukkan bahwa responden penelitian paling banyak pada keadaan tahan pangan. Akan tetapi merujuk pada tabel 2, responden dengan keadaan tahan pangan tidak merata di semua responden. Responden dengan balita stunting lebih banyak merupakan responden dengan kerawanan keluarga yang rawan sedang dan rawan berat, sedangkan responden yang tidak dengan balita stunting lebih banyak merupakan responden yang tahan pangan. Analisis data juga menunjukkan bahwa terdapat hubungan antara kerawanan pangan terhadap stunting. Hasil penelitian ini sesuai dengan penelitian di Bangladesh yang menunjukkan bahwa keluarga rawan pangan ringan dan sedang memiliki kemungkinan lebih besar untuk memiliki anak stunting dibandingkan keluarga lain dengan ketersediaan pangan berkelanjutan (Sarma, et al., 2017). Lebih lanjut, bayi usia 6-23 bulan dalam keluarga dengan ketersediaan pangan rawan memiliki risiko 2,7 kali lipat mengalami stunting dibandingkan dengan bayi dalam keluarga dengan ketersediaan pangan berkelanjutan (Masrin, 2014). Kemudahan untuk mendapatkan sumber pangan akan berpengaruh terhadap kecukupan gizi bagi keluarga terutama bagi ibu dan balitanya, sehingga kerawanan pangan yang disebabkan oleh keterbatasan aset dan akses ke sumber pangan akan menyebabkan masalah gizi pada balita termasuk stunting (Firman \& Mahmudiono, 2018; Pangestuti, dkk., 2017). Kerentanan pasokan pangan keluarga dalam jangka panjang dapat mempengaruhi konsumsi pangan dengan terus menerus mengurangi kuantitas dan kualitas pangan bagi seluruh anggota keluarga termasuk balita, sehingga kekurangan gizi yang dibutuhkan tubuh anak akan berdampak negatif pada pertumbuhan balita terutama pada tinggi tubuh, yang akan menyebabkan stunting (Chaparro, 2012). Untuk mendapatkan asupan gizi seimbang diperlukan kecukupan makan 3 kali sehari. Hal tersebut dinyatakan pada pesan ke tujuh dasar gizi seimbang untuk membiasakan sarapan pagi. Selain itu, juga disarankan untuk makan siang dan makan malam yang terdiri dari 4 kelompok makanan (makanan pokok, lauk pauk, sayur dan buah). Oleh karena itu, apabila seseorang mengalami kekurangan kecukupan makan per hari akan berakibat tidak diperolehnya asupan gizi yang seimbang atau nutrisi yang kurang baik (Food and Agriculture Organization, 2011). Lebih lanjut, Bloem (2010) menyatakan bahwa nutrisi yang baik berkaitan dengan pencegahan berkembangnya infeksi penyakit termasuk tuberculosis dan stunting.

Hasil penelitian ini menunjukkan bahwa responden sebagian besar mempunyai keragaman makanan yang tinggi. Merujuk pada tabel 2, walaupun terdapat perbedaan persentase responden dengan balita stunting dan tidak dengan balita stunting menurut keragaman makanan, tetapi perbedaan tersebut tidak terlalu besar. Analisis data menunjukkan bahwa tidak terdapat hubungan antara keragaman makanan terhadap stunting. Hasil tersebut tidak sesuai dengan review yang menyatakan bahwa untuk hidup dan meningkatkan kualitas hidup, seseorang memerlukan 5 kelompok zat gizi (karbohidrat, protein, lemak, vitamin dan mineral) dalam jumlah cukup, tidak berlebihan dan tidak juga kekurangan. Selain itu, diperlukan juga air dan serat untuk memperlancar berbagai proses faali dalam tubuh. Di sisi lain, secara alami, komposisi zat gizi setiap jenis makanan memiliki keunggulan dan kelemahan tertentu. Beberapa makanan mengandung tinggi karbohidrat tetapi kurang vitamin dan mineral. Sedangkan beberapa makanan lain kaya vitamin $C$ tetapi miskin vitamin A. Apabila konsumsi makanan sehari-hari kurang beranekaragam, maka akan timbul ketidakseimbangan antara masukan dan kebutuhan zat gizi yang diperlukan untuk hidup sehat dan produktif. Dengan mengonsumsi makanan seharihari yang beranekaragam, kekurangan zat gizi pada jenis makanan yang satu akan dilengkapi oleh keunggulan susunan zat gizi jenis makanan lain, sehingga diperoleh masukan zat gizi yang seimbang (Food and Agriculture Organization, 2011). Pada penelitian ini tidak terdapatnya hubungan antara ragam makanan dan stunting dapat disebabkan karena tidak terlalu banyak perbedaan antara balita yang stunting dan tidak stunting menurut keragaman makanan.

Penelitian ini juga menunjukkan hasil bahwa keluarga dengan kerawanan pangan keluarga yang sedang-berat sebagian besar merupakan keluarga dengan pendidikan ibu yang rendah dan pendapatan keluarga yang juga rendah. Sedangkan pada keluarga dengan kerawanan 
pangan yang ringan-tahan pangan merupakan keluarga dengan pendidikan ibu yang tinggi dan pendapatan keluarga yang sedang-tinggi. Hasil penelitian ini sesuai dengan penelitian yang juga mendapatkan hasil bahwa pendapatan keluarga yang rendah, tingkat pendidikan ibu yang rendah, dan pengetahuan gizi ibu yang buruk merupakan faktor-faktor yang berhubungan dengan kasus balita stunting (Ni'mah, dkk., 2015). Lebih lanjut, pendapatan keluarga berhubungan dengan kemampuan rumah tangga untuk memenuhi kebutuhan hidup primer, sekunder, dan tersier. Keterbatasan pendapatan keluarga akan mempengaruhi kualitas dan kuantitas bahan pangan yang akan dikonsumsi oleh anggota keluarga (Khotimah, 2014). Hasil penelitian ini juga sesuai dengan penelitian yang dilakukan oleh Dean dan Sharkey (2011) di Texas yang mendapatkan adanya hubungan antara pendidikan dan pendapatan keluarga dengan kecukupan bahan pangan. Pada penelitian tersebut pendidikan yang tinggi merupakan faktor yang bersifat protektif terhadap kecukupan bahan pangan $(\mathrm{OR}=0,88)$. Pada penelitian tersebut, pendapatan yang sangat rendah juga merupakan faktor risiko untuk seringnya mengalami ketidakcukupan bahan makanan dan tidak adanya uang untuk membeli $(\mathrm{OR}=4,61)$. Sedangkan pendapatan rendah merupakan faktor risiko untuk kadang-kadang mengalami ketidakcukupan bahan makanan $(\mathrm{OR}=3,57)$. Hasil penelitian ini juga sesuai dengan penelitian yang dilakukan oleh Hur, Jang dan Oh (2011) di Korea yang mendapatkan hasil bahwa asupan protein, kalsium, fosfor, potasium dan vitamin $\mathrm{C}$ berhubungan dengan pendapatan keluarga. Keluarga dengan pendapatan yang rendah akan mempunyai risiko lebih tinggi untuk

\section{DAFTAR PUSTAKA}

Aromolaran, A.B. (2004). Household Income, Women's Income Share and Food Calorie Intake in South Western Nigeria. Food Policy, 29: 507-530.

Badan Pusat Statistik Provinsi Lampung. (2016). Indikator Makro Ekonomi Regional Provinsi Lampung 2016. Bandar Lampung: BPS Provinsi Lampung.

Bloem, M.W. \& Saadeh, R. (2010). Foreword: The Role of Nutrition and Food Insecurity in mendapatkan asupan protein, kalsium, fosfor, potasium dan vitamin $\mathrm{C}$ yang rendah. Akan tetapi, hasil penelitian ini tidak sesuai dengan Aromolaran (2004) yang pada penelitiannya di Nigeria Barat Daya mendapatkan hasil bahwa meningkatnya sumbangan pendapatan istri dalam pendapatan keluarga tidak berhubungan dengan peningkatan asupan kalori keluarga. Hal tersebut didukung oleh data bahwa keluarga dengan sumbangan pendapatan istri yang lebih besar, lebih banyak berasal dari keluarga dengan pendapatan keluarga yang rendah. Misselhorn (2005) berdasarkan meta analisis penelitian keamanan pangan di Afrika Selatan menyatakan bahwa kemiskinan berkaitan erat dengan ketidakamanan pangan. Review yang dilakukan oleh Chopra dan Sanders (2008) juga mendapatkan bahwa persentase anak kurang gizi di Sub Sahara Afrika semakin menurun seiring dengan menurunnya persentase pendapatan rumah tangga yang berada di bawah garis kemiskinan. Lebih jauh, Lönnroth (2009 dan 2010) menyatakan bahwa orang dengan pendidikan, pekerjaan, pendapatan dan kelas sosial yang rendah cenderung mempunyai ketidakamanan pangan yang besar.

\section{SIMPULAN}

Berdasarkan hasil penelitian dapat disimpulkan bahwa faktor sosial ekonomi (pendidikan dan pendapatan) dan faktor ketahanan pangan (kerawanan pangan keluarga) berhubungan dengan kejadian stunting pada balita. Oleh karena itu, program penanggulangan stunting perlu mengimplementasikan intervensi kedua faktor tersebut untuk menurunkan kejadian stunting.

HIV and Tuberculosis Infections and The Implications for Interventions in Resourcelimited Settings. Food Nutrition Bulletin, 31(3).

Braveman, P. A, Egerter, S. A, \& Mockenhaupt, R. E. (2011). Broadening the Focus: The Need to Address the Social Determinants of Health. American Journal of Preventive Medicine, 40, S4-18. 
Budge, S., Parker, A.H., Hutchings, P.T. \& Garbutt, C. (2019). Environmental Enteric Dysfunction and Child Stunting. Nutrition Reviews, 77(4): 240-253.

Chaparro, C. (2012). Household Food Insecurity and Nutritional Status of Women of Reproductive Age and Children under 5 Years of Age in Five Departments of the Western Highlands of Guatemala: An Analysis of Data from the National Maternal Infant Health Survey 2008-09 of Guatemala. Washington, DC.: FAO

Chopra, M. \& Sanders, D. (2008). Undernutrition and Its Social Determinants. International Encyclopedia of Public Health, p.421-426.

Coates, J., Swindale, A., Bilinsky, P. (2007). Household Food Insecurity Access Scale (HFIAS) for Measurement of Food Access: Indicator Guide. Food and Nutrition Technical Assistance III Project (FANTA). Washington, DC: FAO.

CSDH. (2011). Closing The Gap: Policy into Practice on Social Determinants of Health. Geneva: WHO.

Dean, W.R. \& Sharkey, J.R. (2011). Food Insecurity, Social Capital and Perceived Personal Disparity in a Predominantly Rural Region of Texas: An Individual-Level Analysis. Social Science \& Medicine, 72: 1454-1462.

Dinas Kesehatan Kota Bandar Lampung. (2018). Laporan tahunan Seksi Gizi Dinas Kesehatan Kota Bandar Lampung tahun 2018. Bandar Lampung: Dinas Kesehatan Kota Bandar Lampung.

Dinas Kesehatan Kota Bandar Lampung. (2015). Hasil Survei Pemantauan Gizi (PSG) Kota Bandar Lampung tahun 2015. Seksi Gizi Bidang Kesehatan Masyarakat. Bandar Lampung: Dinas Kesehatan Kota Bandar Lampung.

Firman, A.N., \& Mahmudiono, T. (2018). Kurangnya Asupan Energi dan Lemak yang Berhubungan dengan Status Gizi Kurang pada Balita Usia 25-60 Bulan. The Indonesian Journal of Public Health, 13(1): 48-58.

Food and Agriculture Organization. (2011). Guidelines for measuring household and individual dietary diversity. Rome:
Nutrition and Consumer Protection Division, Food and Agriculture Organization of the United Nations..

Huicho, L., Espinoza,CAH., Perez, EH., Segura, ER., de Guzman,JN., María Rivera,M.Ch., and Barros, A.J.D. (2017). Factors behind the success story of under-five stunting in Peru: a district ecological multilevel analysis. BMC Pediatrics, 17:29

Hur, I., Jang, M-J., \& Oh, K. (2011). Food and Nutrient Intakes According to Income in Korean Men and Women. Public Health Res Perspect, 2(3): 192-197.

Kementrian Kesehatan RI. (2018). Situasi Balita Pendek (Stunting) di Indonesia. Jakarta: Buletin Jendela Data dan Informasi Kesehatan.

Khoeroh, H., \& Indriyanti, D. (2015). Evaluasi Penatalaksanaan Gizi Balita Stunting di Wilayah Kerja Puskesmas Sirampog, Unnes Journal of Public Health, 4(1): 54-60.

Khotimah, H. \& Kuswandi, K. (2014). Hubungan Karakteristik Ibu Dengan Status Gizi Balita Di Desa Sumur Bandung Kecamatan Cikulur Kabupaten Lebak Tahun 2013. Jurnal Obstretika Scienta, 2(1):146-162

Lönnroth, et.al. (2010). A consistent log-linear relationship between tuberculosis incidence and body mass index. International Journal of Epidemiology, 39:149-155.

Lönnroth, Jaramillo E., Williams B.G., Dye, C., Raviglione M. (2009). Driver of tuberculosis epidemics: The role of risk factors and social determinants. Social Science \& Medicine, 68(12): 2240-2246.

Masrin, Paratmanitya, Y., Aprilia, V. (2014). Ketahanan Pangan Rumah Tangga berhubungan dengan Stunting pada Anak Usia 6-23 Bulan. Jurnal Gizi dan Dietetik Indonesia, 2(3): 103-115.

Michaelsen, K.F., Stewart, C.P., Dewey, K.G., Onyango, A.W. \& Innouti, L. (2015). Contextualizing Complementary Feeding in A Broader Framework for Stunting Prevention. Maternal \& Child Nutrition, 9(Sp2): 27-45.

Misselhorn, A.A. (2005). What Drives Food Insecurity in Southern Africa? A MetaAnalysis of Household Economy Studies. Global Environmental Change, 15:33-43. 
Mustikaningrum, AC., Subagio, HW., Margawati, A. (2016). Determinan kejadian stunting pada bayi usia 6 bulan di kota Semarang. Jurnal Gizi Indonesia, 4(2): 82-88.

Ni'mah, K., \& Nadhiroh, S. R. (2015). Faktor yang Berhubungan dengan Kejadian Stunting pada Balita. Media Gizi Indonesia, 10 (1): 13-19.

Nurbaiti, L., Adi, A.C., Devi, S.R., \& Harthana, T., (2014). Kebiasaan Makan Balita Stunting pada Masyarakat Suku Sasak: Tinjauan 1000 Hari Pertama Kehidupan (HPK). Masyarakat, Kebudayaan dan Politik, 27(2): 104-112.

Oktarina, Z., \&Sudiarti, T. (2014). Faktor Risiko Stunting pada Balita (24-59 Bulan) di Sumatra. Jurnal Gizi dan Pangan, 8(3): 175-180.

Pangestuti., A.M.S., Rahayuning, D. \& Aruben, R. (2017). Hubungan Ketahanan Pangan Keluarga dan Pola Konsumsi dengan Status Gizi Balita Keluarga Petani. Jurnal Kesehatan Masyarakat, 5(3): 120-128.

Pemerintah RI. (2008). Peraturan Pemerintah Republik Indonesia Nomor 47 Tahun 2008 Tentang Wajib Belajar. Jakarta.

Pemerintah RI. (2012). Undang-undang Republik Indonesia nomor 18 tahun 2012 tentang Pangan. Jakarta.

Prendergast, A.J., \& Humphrey, J.H. (2014). The Stunting Syndrome in eveloping Countries. Pediatrics and International Child Health, 34(4): 250-265.
Sarma, H., Asaduzzaman, M., Khan,JR., Tarannum,S., Uddin, F., Rahman, AS., Hasan, M., and Ahmed, T. (2017). Factors Influencing the Prevalence of Stunting Among Children Aged Below Five Years in Bangladesh. Food and Nutrition Bulletin, 38(3): 291-301.

Tiwari, R., Ausman, L. M., Argho, K. E. (2014). Determinants of stunting and severe stunting among under-fives: evidence from 2011 Nepal Demographic and Health Survey. BMC Pediatrics, 14 (239).

UNICEF. (2013). Improving child nutrition, the achievable imperative for global progress. New York: United Nations Children's Fund.

Wardani, D., \& Wahono, E. (2018). Prediction Model of Tuberculosis Transmission Based on Its Risk Factors and Socioeconomic Position in Indonesia. Indian Journal of Community Medicine, 43(2).

World Health Organizatition. (2013). Childhood Stunting: Context, Causes and Consequences. WHO Conceptual Framework. Geneva: WHO.

World Health Organizatition. (2006). Multicentre Growth Reference Study Group. WHO Child Growth Standards: Length/Heightfor-Age, Weight-for-Age, Weightfor-Length, Weight-for-Height and Body Mass Indexfor-Age: Methods and Development. Geneva: WHO. 